\title{
Properties of Granular Nitrogen-Containing Fertilizers Based on Pine Sawdust and Studying its Effectiveness \\ in Growing Wheat in the Agricultural Zone of the Krasnoyarsk Territory
}

\author{
Vasily N. Romanova, Natalia S. Kozulina ${ }^{a}$, \\ Tatiana A. Snitkova ${ }^{a}$, Albina V. Vasilenko ${ }^{a}$, \\ Mikhail A. Mikhailets ${ }^{a}$, Alexey G. Lipshina, \\ Mikhail Yu. Belash ${ }^{b}$, Evgenia V. Veprikova*b. \\ Anatoly A. Sobolev ${ }^{\mathrm{b}}$ and Oxana P. Taran ${ }^{\mathrm{b}, \mathrm{c}}$ \\ ${ }^{a}$ Krasnoyarsk research institute of agriculture, \\ $F R C$ «Krasnoyarsk Scientific Center of the SB RAS» \\ Krasnoyarsk, Russian Federation \\ ${ }^{b}$ Institute of Chemistry and Chemical Technology SB RAS \\ $F R C$ «Krasnoyarsk Scientific Center of the $S B$ RAS» \\ Krasnoyarsk, Russian Federation \\ 'Siberian Federal University \\ Krasnoyarsk, Russian Federation
}

Received 11.11.2021, received in revised form 15.11.2021, accepted 05.12.2021

\begin{abstract}
A method for producing granular fertilizers based on pine sawdust containing ammonium nitrate is proposed. Physico-chemical properties of sawdust and fertilizers containing $20.0 \mathrm{wt} . \%$ nitrogen were studied. The effect of pretreatment of pine sawdust with $1 \%$ wt. with a water solution of $\mathrm{NaOH}$ on the properties of granular fertilizers was explored. The results of a field trial on the cultivation of wheat varieties «Krasnoyarskaya 12» revealed the growth-stimulating effect of nitrogen-containing granular fertilizers in comparison with an unfertilized background. A more effective influenceon wheat yield of granular fertilizer fabricated from pine sawdust after their treatment with $1 \%$ wt. with a water solution of $\mathrm{NaOHThe}$ achieved effect on $1,9 \mathrm{c} /$ ha higher in comparison with thefertilizer based on original sawdust.
\end{abstract}

Keywords: pine sawdust, ammonium nitrate, granulation, wheat, field experiment, seed yield.

(C) Siberian Federal University. All rights reserved

This work is licensed under a Creative Commons Attribution-NonCommercial 4.0 International License (CC BY-NC 4.0).

* Corresponding author E-mail address: veprikova2@mail.ru 
Acknowledgments. The work was carried out within the project No. 0287-2019-0009 using the equipment of the Krasnoyarsk Regional Center for Collective Use of the Federal Research Center of the KSC SB RAS.

Citation: Romanov, V.N., Kozulina, N. S., Snitkova, T. A., Vasilenko, A. V., Mikhailets, M. A., Lipshin, A. G., Belash, M. Yu., Veprikova, E. V., Sobolev, A. A., Taran, O. P. Properties of granular nitrogen-containing fertilizers based on pine sawdust and studying its effectiveness in growing wheat in the agricultural zone of the Krasnoyarsk Territory, J. Sib. Fed. Univ. Chem., 2021, 14(4), 570-581. DOI: 10.17516/1998-2836-0264

\title{
Свойства гранулированных азотсодержащих удобрений на основе сосновых опилок и исследование их эффективности при выращивании пшеницы
}

в земледельческой зоне Красноярского края

\author{
В.Н. Романов ${ }^{a}$, Н.С. Козулина ${ }^{a}$, \\ Т. А. Сныткова ${ }^{a}$, А. В. Василенко \\ М.А. Михайлеца ${ }^{a}$ А. Г. Липшин ${ }^{\mathrm{a}}$ М. Ю. Белаш ${ }^{0}$,

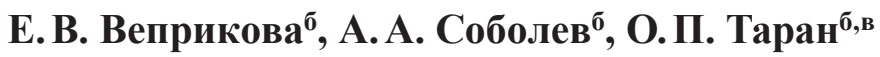 \\ ${ }^{a}$ Красноярский научно-исследовательский институт \\ сельского хозяйства \\ ФИЦ КНЦ СО РАН \\ Российская Федераџия, Красноярск \\ ${ }^{\sigma}$ Институт химии и химической технологии СО РАН \\ ФИЦ КНЦ СО РАН \\ Российская Федераџия, Красноярск \\ ${ }^{8}$ Сибирский федеральньий университет \\ Российская Федераџия, Красноярск
}

Аннотация. Предложен способ получения гранулированных удобрений на основе сосновых опилок, содержащих аммиачную селитру. Исследованы физико-химические свойства опилок и удобрений, содержащих 20,0 \% мас. азота. Изучено влияние предварительной обработки сосновых опилок $1 \%$ мас. водным раствором $\mathrm{NaOH}$ на свойства гранулированных удобрений. Результаты полевого испытания по выращиванию пшеницы сорта «Красноярская 12» выявили ростостимулирующее влияние азотсодержащих гранулированных удобрений по сравнению с неудобренным фоном. Установлено более эффективное влияние на урожайность пшеницы гранулированного удобрения, полученного из сосновых опилок после их обработки 1 \% мас. водным раствором $\mathrm{NaOH}$ - по данному показателю достигаемый эффект на 1,9 ц/га больше в сравнении с аналогичным удобрением на основе исходных опилок.

Ключевые слова: сосновые опилки, аммиачная селитра, гранулирование, пшеница, полевой опыт, урожайность зерна. 
Благодарности. Работа выполнена в рамках проекта № 0287-2019-0009 с использованием оборудования Красноярского регионального центра коллективного пользования ФИЦ КНЦ CO РAH.

Цитирование: Романов, В.Н. Свойства гранулированных азотсодержащих удобрений на основе сосновых опилок и исследование их эффективности при выращивании пшеницы в земледельческой зоне Красноярского края / В.Н. Романов, Н. С. Козулина, Т. А. Сныткова, А. В. Василенко, М. А. Михайлец, А. Г. Липшин, М. Ю. Белаш, Е. В. Веприкова, А. А. Соболев, О.П. Таран // Журн. Сиб. федер. ун-та. Химия, 2021, 14(4). C. 570-581. DOI: 10.17516/1998-2836-0264

\section{Введение}

Проблема утилизации древесных отходов в нашей стране считается одной из наиболее актуальных, так как в настоящее время при существующих методах переработки теряется почти половина биомассы дерева $[1,2]$.

Один из способов утилизации древесных отходов, в частности опилок, - получение органоминеральных удобрений [3]. Наиболее перспективными являются гранулированные удобрения, поскольку обеспечивают снижение трудозатрат на их внесение в почву. С другой стороны, гранулирование позволяет обеспечить замедленное удаление водой элементов питания из гранул и, следовательно, более эффективное их потребление растениями в период вегетации. Азот является основным элементом для достижения высокой урожайности сельскохозяйственных культур и их качества. Известно, что интенсивное применение традиционных азотсодержащих минеральных удобрений сопровождается неблагоприятными экологическими рисками за счет увеличения эвтрофикации природных вод и эмиссии закиси азота [4]. Внедрение азотсодержащих удобрений пролонгированного действия в аграрную область позволит сократить объемы применяемых минеральных водорастворимых удобрений, что обеспечит снижение негативного воздействия на экологию при большем экономическом эффекте [5]. Сдерживающим фактором масштабного применения удобрений пролонгированного действия считается их высокая стоимость, особенно удобрений оболочечного типа. В этом отношении весьма привлекательны гранулированные удобрения на основе древесных отходов, содержащие различные минеральные компоненты.

Обзор литературы показал, что возможность гранулирования смеси древесных опилок с аммиачной селитрой, особенно при высоких содержаниях последней, практически не рассматривается. Это обусловлено, очевидно, ее разложением при температуре выше $110^{\circ} \mathrm{C}[6]$. В процессе гранулирования за счет саморазогрева температура формуемой смеси может превышать это значение [7]. Поэтому разработка способа получения гранул из древесных опилок в сочетании с аммиачной селитрой представляет интерес. Так как аммиачная селитра широко применяется в сельском хозяйстве, содержащие ее гранулированные материалы могут служить удобрением. Для выявления ростостимулирующего действия вновь предлагаемых удобрений актуальны исследования по выращиванию сельскохозяйственных культур в полевых условиях, позволяющие определить их влияние на урожайность и качество продукции.

Цель работы - разработка способа получения на основе сосновых опилок гранулированных удобрений, содержащих аммиачную селитру, а также изучение их свойств и исследование влияния удобрений на продуктивность яровой пшеницы сорта «Красноярская 12».

$$
-572 \text { - }
$$




\section{Экспериментальная часть}

Получение гранулированных удобрений

Сырьем для получения удобрений служили воздушно-сухие опилки сосны (Pinus Sylvestris L.). Влажность опилок - 3,0-3,6 \%, содержание золы - 0,3 \%. Опилки измельчали и выделяли фракцию размером менее 3 мм.

Для получения удобрений применяли исходные опилки и опилки, предварительно обработанные 1,0\%-ным водным раствором $\mathrm{NaOH}$. Водно-щелочной гидролиз проводили при следующих условиях: температура $93 \pm 3{ }^{\circ} \mathrm{C}$; продолжительность 1 ч; значение гидромодуля равно 15; перемешивание. Промывку подложки водой и нейтрализацию остатков щелочи раствором 0,1 $\mathrm{NHNO}_{3}$ (гидромодуль - 10) проводили аналогично методике [8]. Подложку сушили до воздушно-сухого состояния при $50 \pm 5^{\circ} \mathrm{C}$.

Получение удобрений включало две основные стадии: 1) нанесение на опилки аммиачной селитры; 2) гранулирование.

Нанесение аммиачной селитры (марка «ч») проводили пропиткой опилок водным раствором из расчета 3,5 л/кг. Количество аммиачной селитры рассчитано так, чтобы удобрение содержало 20,0 мас. \% азота. Пропитанные опилки уплотняли и выдерживали в закрытой таре в течение 15-20 ч при комнатной температуре. Затем сушили при $100-105^{\circ} \mathrm{C}$ до остаточной влажности $12,7-15,5 \%$.

Гранулирование опилок, содержащих аммиачную селитру, проводили на грануляторе ZLSP - 150 (Китай), используя матрицу с диаметром отверстий 4 мм. В процессе грануляции периодически контролировали температуру опилок, которая не должна превышать $85-90{ }^{\circ} \mathrm{C}$. Если на выходе получали рыхлые, легко распадающиеся гранулы, процесс грануляции повторяли.

На основе исходных опилок и опилок, обработанных щелочью, было приготовлено по 10 кг азотсодержащих удобрений следующего состава (мас. \%): 42,85 - опилки сосны, 57,15 - аммиачная селитра.

Изучение физико-химических свойств сосновых опилок

и удобрений на их основе

Влажность, зольность сосновых опилок, содержание в них лигнина (в модификации Комарова) определяли по методикам [9], влагоемкость - по ГОСТ 24160-80, общее количество полифенольных соединений - методом пересчета на кислоту галловую по ГОСТ Р ИСО 14502-1-2010. Насыпную плотность гранулированных удобрений определяли согласно ГОСТ 28512.1-90. Для оценки механической прочности гранул удобрений применяли методику работы [10]. Для отсева разрушенных частиц использованы сита с отверстиями 1 и 3 мм.

Пористую структуру сосновых опилок исследовали методом низкотемпературной адсорбции азота в интервале ( $\mathrm{P} / \mathrm{P}_{\text {o }}$ ) 0.06-0.99 на анализаторе ASAP 2029MP-C (Micromeritics, США). Площадь удельной поверхности $\left(\mathrm{S}_{\mathrm{BET}}, \mathrm{M}^{2} / \Gamma\right)$ и объем микропор $\left(\mathrm{V}_{\mathrm{mi}}, \mathrm{cm}^{3} / \Gamma\right)$ рассчитывали по методу БЭТ [11]. Объем мезопор и макропор шириной до 300 нм $\left(\mathrm{V}_{\mathrm{me-mac}}, \mathrm{cm}^{3} / \Gamma\right)$ был рассчитан с помощью метода ВJH (Barrett - Joyner - Halenda) [12].

Регистрация ИК-спектров сосновых опилок, удобрений на их основе и аммиачной селитры выполнена на ИК-Фурье спектрометре IR Tracer-100 (Shimadzu, Япония) в области волновых

$$
-573-
$$


чисел 4000-400 см-1. Образцы готовили в виде таблеток в матрице бромистого калия при одинаковых условиях (3 мг на 1000 мг бромида калия).

\section{Проведение полевых испытаний}

Влияние азотсодержащих удобрений на основе сосновых опилок на продуктивность яровой пшеницы сорта «Красноярская 12» изучалось в сравнении с аммиачной селитрой и неудобренным фоном (контроль) в условиях стационарного полевого опыта. Предшественник - яровая пшеница, обработка почвы - весновспашка на 20-22 см. Полевой опыт проводился на участке, расположенном в зоне Красноярской лесостепи, с географическими координатами: широта $56^{\circ}$ 03' СШ, и 92 42' ВД. Период проведения опыта - с 8 мая по 8 сентября 2021 г. Почва на участке представляет собой чернозем обыкновенный, маломощный, среднесуглинистый. Выбор участка, схема закладки опыта и фенологические наблюдения проведены по методикам [13] 30 апреля 2021 г. Площадь участков под внесение удобрений составляла 400 м² $^{2}$ учетная площадь (площадь контрольного участка) - 25,2 м $^{2}$. Размещение вариантов опыта на площади очередное, повторность 3-кратная. Вспашка опытного участка проведена 8 мая на глубину 20-22 см. Дискование поверхности проведено 10 мая. Внесение удобрений (аммиачной селитры, УД-1 и УД-2) проходило перед вспашкой поверхностно, с последующей запашкой на глубину до 22 см.

Норма внесения азотсодержащего удобрения УД-1 составляла 80 кг/га, УД-2 - 70 кг/га, аммиачной селитры - 100 кг/га. Посев семян пшеницы проводили на глубину 5 см 30 мая 2021 г. Норма высева семян пшеницы - 3,5 млн шт. на 1 га (150,5 кг семян пшеницы на 1 га).

Посевы пшеницы в полевом опыте характеризовали по общепринятым методикам [14]. Образцы почвы для определения содержания влаги были отобраны 27 мая на глубину 0,5 м через 10 см. Одновременно произведен отбор образцов почвы для определения содержания элементов питания. Отбор проб почвы и ее анализ осуществлены по методикам ГОСТ 5898-2019 и [15]. Достоверность влияния внесения удобрений на урожайность пшеницы $\left(\mathrm{HCP}_{05}\right)$ оценивали с помощью дисперсионного анализа [16]. Уборка урожая проведена 8 сентября.

Данные о погодных условиях в зоне проведения полевого опыта по сведениям интернет портала http:// ru-meteo.ru (май - сентябрь 2021 г.) приведены в табл. 1. За июль - август 2021 г. выпало 230 мм осадков при средней температуре $17,5^{\circ} \mathrm{C}$.

\section{Результаты и обсуждение}

Свойства гранулированных азотсодержаших удобрений

на основе сосновых опилок

Для повышения устойчивости удобрений к удалению азота водой при их получении одновременно использованы два метода: 1) пропитка сосновых опилок, обладающих специфической пористой структурой, раствором аммиачной селитры; 2) гранулирование. Способность к медленному удалению азота из полученных удобрений достигается за счет внутридиффузионных затруднений перехода аммиачной селитры из объема гранул в почвенный раствор и после распада гранул - переходом нанесенного вещества из пор.

Сосновые опилки в составе удобрений выполняли функцию пористой подложки для нанесения аммиачной селитры. Параметры пористой структуры исходных сосновых опилок и опилок после обработки 1,0\%-ным водным раствором $\mathrm{NaOH}$ приведены в табл. 2.

$$
-574-
$$


Таблица 1. Погодные условия вегетационного периода полевого опыта 2021 г.

Table 1. Weather conditions in vegetative season of the field experiment 2021 year

\begin{tabular}{|c|c|c|}
\hline \multirow{2}{*}{ Дата } & Температура воздуха, ${ }^{\circ} \mathrm{C}$ & \multirow{2}{*}{ Осадки, мм } \\
\cline { 1 - 2 } & Средняя & 122 \\
\hline За июнь & 15,5 & 47 \\
\hline За июль & 19,7 & 61 \\
\hline За август & 17,4 & 230 \\
\hline За июнь - август & 17,5 & \\
\hline
\end{tabular}

Таблица 2. Физико-химические свойства сосновых опилок

Table 2. Physical and chemico-properties of pine sawdust

\begin{tabular}{|c|c|c|c|c|c|c|c|}
\hline \multirow{2}{*}{ Образец } & \multirow{2}{*}{$\mathrm{S}_{\mathrm{BET}}, \mathrm{M}^{2} / \Gamma$} & \multicolumn{3}{|c|}{ Объем пор, $\mathrm{cm}^{3} / \Gamma, \times 10^{-4}$} & \multirow{2}{*}{ ВЛ. г/Г } & \multirow{2}{*}{ ПФ, \% } & \multirow{2}{*}{ Лигнин, \% } \\
\hline & & $\mathrm{V}_{\text {tot }}$ & $\mathrm{V}_{\text {mic }}$ & $\mathrm{V}_{\text {me-mac }}$ & & & \\
\hline Сосновые опилки & 0,437 & 8,74 & 0,49 & 8,25 & 3,63 & 0,15 & 32,78 \\
\hline $\begin{array}{l}\text { Сосновые опилки после } \\
\text { обработки } 1.0 \% \text { растворомNaOH }\end{array}$ & 0,454 & 12,43 & 0,76 & 11,67 & 4,85 & 0,05 & 40,07 \\
\hline
\end{tabular}

Примечание. $\mathrm{S}_{\mathrm{BET}}$ - удельная площадь поверхности, $\mathrm{V}_{\mathrm{tot}}-$ общий объем пор шириной до 300 нм, $\mathrm{V}_{\mathrm{mic}}-$ объем микропор, $\mathrm{V}_{\text {me-mac }}$ - объем мезопор и макропор шириной до 300 нм, ВЛ - влагоемкость, ПФ - содержание полифенольных веществ.

Обработка опилок 1,0\%-ным водным раствором $\mathrm{NaOH}$ при выбранных условиях позволила удалить 21,9 \% различных органических веществ. В результате в структуре опилок увеличился объем пор: микропор в 1,55 раз, а мезо- и макропор шириной до 300 нм в 1,4 раза. Увеличение пористости данного образца приводит к большей его проницаемости для молекул воды, что следует из сравнения значений влагоемкости исходных и обработанных щелочью опилок (табл. 2). Это может обеспечивать более равномерное распределение аммиачной селитры по поверхности опилок.

Особенностью анатомического строения древесины сосны является высокое содержание трахеид (вытянутые одревесневшие клетки растений, служащие транспортером воды и минеральных солей), на долю которых приходится до 93,1 \%. Средний диаметр трахеид варьируется от 10 до 50 мкм, а длина - от 1,4 до 4,4 мм. Стенки трахеид покрыты порами размером 0,8-3,0 мкм [17]. Трахеиды способны обеспечить транспорт молекул аммиачной селитры в более мелкие поры. Локализация молекул этого вещества в микро-, мезо- и мелких макропорах может способствовать их медленному удалению в процессе обработки удобрений водой.

Сосновые опилки характеризуются невысоким содержанием полифенольных веществ не более $0,15 \%$, а щелочная обработка приводит к снижению их содержания в 3 раза (табл. 2). Известно, что древесина сосны содержит различные фенольные соединения, в том числе и феруловую кислоту [18]. Феруловая кислота оказывает негативное действие на ростовую активность растений за счет ингибирования у растений нитратредуктазы, фосфорилазы, глютаматдегидрогеназы, которые являются ключевыми метаболитами их нормального развития [19]. Длительное внесение в почву лигноцеллюлозных отходов без предварительного 
компостирования приводит к накоплению в ней веществ фенольной природы и повышению ее фитотоксичности. Поэтому сравнение результатов полевого опыта по выращиванию пшеницы с использованием удобрений на основе исходных и обработанных опилок позволит оценить необходимость применения стадии водно-щелочного гидролиза при получении удобрений.

Сосновые опилки содержат 32,78 и 40,07 \% лигнина (табл. 2). В результате биоразложения удобрений в почве из лигнина образуются гумусовые вещества. Считается, что содержащийся в клетках древесины лигнин, выделяющийся под действием давления и температуры, служит связующим веществом в грануле [7]. Следовательно, большее содержание лигнина в опилках после обработки 1,0\%-ным водным раствором $\mathrm{NaOH}$ по сравнению с исходными опилками способствует получению более плотных и прочных гранул (табл. 2 и 3).

Полученные образцы сосновых опилок и азотсодержащие удобрения на их основе изучены методом ИК-спектроскопии (рис. 1).

В ИК-спектрах удобрений на основе сосновых опилок идентифицированы полосы поглощения колебания структурных групп аммиачной селитры, в частности п. п. при 3035, 1399, 1384, 1042, 827 и 714 cм$^{-1}$ [20]. Отмечено отсутствие сдвига характеристических полос поглощения аммиачной селитры в составе удобрений в сравнении с индивидуальным веществом (рис. 1, кривые 3-5). Этот факт подтверждает термостабильность аммиачной селитры в процессе получения гранулированных удобрений. Выявлена неизменность характеристических полос поглощения как исходных образцов сосновых опилок, так и удобрений на их основе (рис. 1, кривые 1-4). Данный факт, как и отсутствие сдвига полос поглощения аммиачной селитры, позволяет судить об отсутствии ее химического взаимодействия с функциональными группами сосновых опилок [20]. Следовательно, в полученных гранулированных удобрениях сохраняется форма нахождения азота, свойственная аммиачной селитре.

\section{Результаты полевого опыта}

Установлено, что при вспашке гранулы с поверхности распределяются по горизонту в такой пропорции: $5 \%$ остаются в поверхностном слое $0-5$ см; 5 \% попадают на глубину 20 см; $90 \%$ распределяются в горизонте 5-15 см. Следовательно, для эффективного действия гранулированных удобрений важна влажность почвы в слое 0-20 см. На стадии посев - всходы влажность этого слоя составила 26,5%. Наблюдаемый уровень влажности почвы способство-

Таблица 3. Характеристики гранулированных азотсодержащих удобрений на основе сосновых опилок Table 3. Characteristics of granular nitrogen-containing fertilizers based on pine sawdust

\begin{tabular}{|c|c|c|c|c|c|}
\hline \multirow[b]{2}{*}{ Образец } & \multirow{2}{*}{$\begin{array}{c}\text { Диаметр } \\
\text { гранул, мм }\end{array}$} & \multirow{2}{*}{$\begin{array}{c}\text { Длина гранул, } \\
\text { мм }\end{array}$} & \multirow{2}{*}{$\begin{array}{c}\text { Насыпная } \\
\text { плотность, г/дм }\end{array}$} & \multicolumn{2}{|c|}{ Механическая прочность, \% } \\
\hline & & & & $\begin{array}{c}\text { Фракция } \\
\geq 1,0 \text { мм }\end{array}$ & $\begin{array}{l}\text { Фракция } \\
\geq 3,0 \text { мм }\end{array}$ \\
\hline УД-1 & $5,2-5,5$ & $5,0-10,2$ & 273,2 & 98,1 & 95,5 \\
\hline УД-2 & $4,5-4,8$ & $8,3-12,1$ & 430,3 & 99,3 & 98,8 \\
\hline
\end{tabular}

Примечание. УД-1 - азотсодержащее удобрение на основе исходных сосновых опилок; Уд-2 - удобрение на основе опилок, обработанных 1,0\%-ным водным раствором $\mathrm{NaOH}$. 


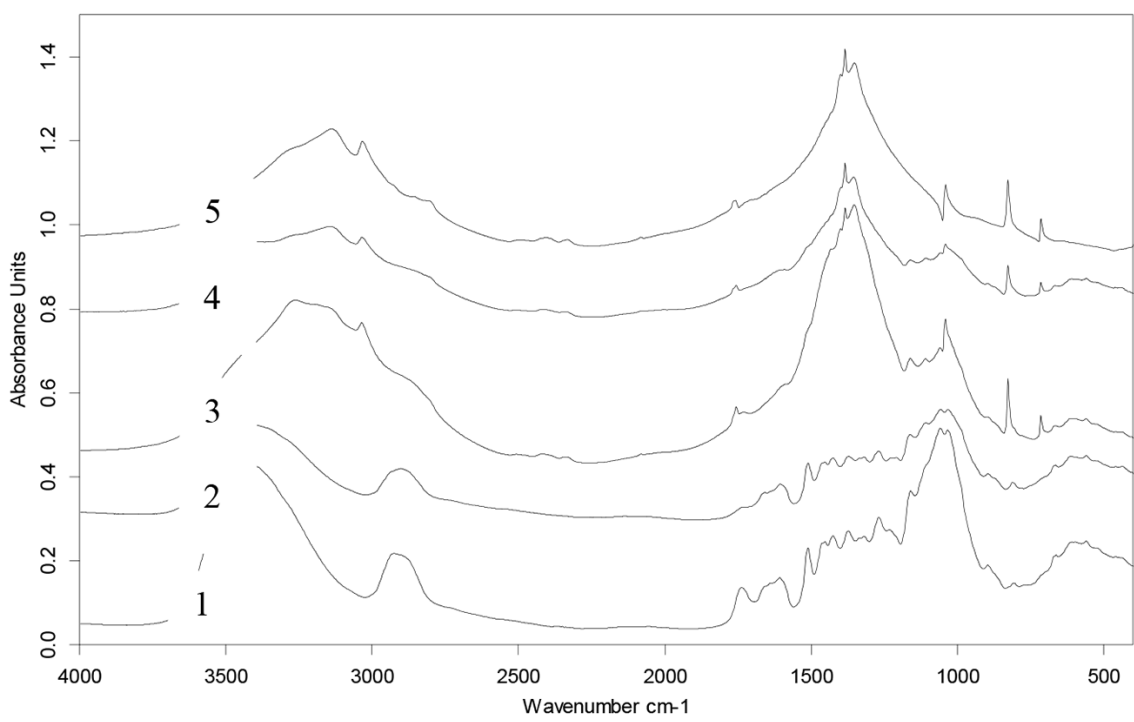

Рис. 1. ИК-спектры исходных сосновых опилок (1), опилок после обработки 1 \% $\mathrm{NaOH}(2)$, азотсодержащих удобрений на их основе (3 и 4 соответственно) и аммиачной селитры (5)

Fig. 1. IR spectra of initial pine sawdust (1), sawdust after treatment with $1 \% \mathrm{NaOH}(2)$, nitrogen-containing fertilizers based on them (3 and 4, respectively) and ammonium nitrate (5)

вал появлению всходов в течение недели (к 7 июня). Прежде всего всходы отмечены на участке с применением аммиачной селитры, через сутки появились всходы на других участках.

В полевом опыте было определено содержание основных элементов питания в почве на разных стадиях вегетации пшеницы при использовании удобрений в сравнении с неудобренным фоном. Для сравнения валовой продуктивности удобрений нормы внесения были выбраны сравнимые: 80, 70 и 100 кг/га для опытов с УД-1, УД-2 и аммиачная селитра соответственно (табл. 4).

Максимальное уменьшение содержания нитратного азота (в 8,6 раза) на стадии колошения пшеницы отмечено в опыте с аммиачной селитрой. В опытах с удобрениями на основе сосновых опилок УД-1 и УД-2 вынос азота меньше (в 4,5 и 3,9 раза соответственно), но при этом наблюдается существенно меньшее содержание азота на стадии всходов. Для УД-1 на этой стадии отмечено незначительное увеличение содержания азота по сравнению с контрольным опытом, а по сравнению с аммиачной селитрой содержание этого элемента в почве меньше в 1,7 раза (табл. 4). Наблюдаемый факт может быть обусловлен существенно меньшим количеством азота, внесенным в почву с гранулированным удобрением, а также замедленным его выделением из гранул.

Сравнение содержаний нитратного азота и фосфора на стадии всходов в контрольном опыте и в опыте с УД-2 свидетельствует о возможной фиксации этих элементов на поверхности гранул удобрения. На стадии колошения содержание нитратного азота в почве во всех опытах с удобрениями отличается мало, и все полученные значения превышают содержание в контрольном опыте.

Содержание подвижного фосфора в почве на стадии всходы - колошение находится в пределах 54,0-88,0 мг/кг почвы (табл. 4). Сравнение с содержанием этого элемента в почве перед 
Таблица 4. Содержание элементов питания в почве (слой 0-20 см)

Table 4. The nutrition elements content in soil

\begin{tabular}{|c|c|c|c|c|c|c|}
\hline \multirow{2}{*}{ Вариант опыта } & \multicolumn{2}{|c|}{$\begin{array}{c}\text { Внесенное удобрение, } \\
\text { кг/га }\end{array}$} & \multicolumn{2}{|c|}{ Нитратный азот, мг/кг } & \multicolumn{2}{|c|}{$\begin{array}{c}\text { Подвижный фосфор, } \\
\text { мг }\end{array}$} \\
\cline { 2 - 7 } & Всего & $\begin{array}{c}\text { Нитратный } \\
\text { азот }\end{array}$ & $\begin{array}{c}01.06 \\
\text { посев }\end{array}$ & $\begin{array}{c}02.08 \\
\text { колошение }\end{array}$ & $\begin{array}{c}01.06 \\
\text { посев }\end{array}$ & $\begin{array}{c}02.08 \\
\text { колошение }\end{array}$ \\
\hline $\begin{array}{c}\text { Без удобрений } \\
\text { (контроль) }\end{array}$ & - & - & 14,7 & 2,9 & 69 & 78 \\
\hline УД-1 & 80 & 2,8 & 16,3 & 3,6 & 75 & 88 \\
\hline УД-2 & 70 & 2,5 & 12,4 & 3,2 & 54 & 65 \\
\hline Аммиачная селитра & 100 & 17,5 & 27,6 & 3,2 & 85 & 82 \\
\hline
\end{tabular}

Примечание. УД-1 - азотсодержащее удобрение на основе исходных сосновых опилок; УД-2 - удобрение на основе опилок, обработанных 1,0\%-ным водным раствором $\mathrm{NaOH}$.

Таблица 5. Характеристика посевов пшеницы сорта «Красноярская 12»

Table 5. Characteristic of sowing of wheat sort «Krasnoyarskay 12»

\begin{tabular}{|l|c|c|c|c|c|c|}
\hline \multirow{2}{*}{ Фон удобрений } & \multicolumn{2}{c|}{ Стебли } & \multicolumn{2}{c|}{ Зерен в колосе } & \multicolumn{3}{c|}{ Урожай } \\
\cline { 2 - 8 } & штук & см & штук & грамм & ц/га & + к контр. \\
\hline Без удобрений (контроль) & 237 & 88 & 27 & 0,90 & 21,4 & - \\
\hline УД -1 & 253 & 85 & 27 & 0,89 & 22,6 & 1,2 \\
\hline УД-2 & 269 & 87 & 26 & 0,91 & 24,5 & 3,1 \\
\hline Аммиачная селитра & 246 & 92 & 30 & 1,07 & 26,4 & 5,0 \\
\hline НСР $_{\text {05 для удобрений }}$ & & & & & & 0,8 \\
\hline
\end{tabular}

Примечание. УД-1 - азотсодержащее удобрение на основе исходных сосновых опилок; УД-2 - удобрение на основе опилок, обработанных 1,0\%-ным водным раствором $\mathrm{NaOH}$.

посевом (фосфора 50,4-67,4 мг/кг) показывает, что в течение вегетации пшеницы не наблюдалось дефицита этого элемента питания.

Наличие питательных элементов в почве в вегетационном периоде обеспечило повышение урожайности пшеницы (табл. 5).

Результаты полевых испытаний показали увеличение урожайности пшеницы при внесении в почву обоих видов азотсодержащих гранулированных удобрений (УД-1 и УД-2) по сравнению с контрольным опытом. Но больший эффект был получен для удобрения УД-2 на основе сосновых опилок, обработанных водным раствором щелочи. Урожайность пшеницы в этом случае на 1,9 ц/га превышает урожайность, наблюдаемую в опыте с удобрением УД-1 на основе исходных (необработанных) опилок.

Таким образом, удобрения на основе сосновых опилок по валовым значениям достигаемой урожайности уступают аммиачной селитре, но в пересчете на вводимый нитратный азот существенно превосходят традиционное удобрение (табл. 5). Применение удобрений пролонгированного действия на основе древесных опилок позволит уменьшить количество минерального азотного удобрения, снизить уровень загрязнения почв и грунтовых вод. Следовательно,

$$
\text { - } 578 \text { - }
$$


дальнейшая оптимизация метода получения удобрений на основе древесных опилок, а также технологии их использования для выращивания пшеницы являются весьма перспективными направлениями исследований.

\section{Заключение}

Разработан способ получения азотсодержащих удобрений, основанный на пропитке сосновых опилок водным раствором аммиачной селитры и их гранулировании, следующего состава (мас. \%): 42,85 опилки сосны, 57,15 аммиачная селитра. Исследования показали эффективность применения предварительной обработки опилок 1,0\%-ным водным раствором $\mathrm{NaOH}$, приводящей к развитию их пористой структуры, уменьшению содержания полифенольных веществ и позволяющей получать более плотные и прочные гранулы.

По результатам проведения полевого опыта по выращиванию пшеницы сорта «Красноярская 12» с применением гранулированных азотсодержащих удобрений на основе сосновых опилок установлено их ростостимулирующее действие - урожайность культуры выросла на 1,2-3,1 ц/га по сравнению с неудобренным вариантом. По достигнутой урожайности удобрение на основе опилок после обработки раствором щелочи на 1,9 ц/га превышает удобрение из исходных сосновых опилок, что позволяет считать его более перспективным для применения в аграрной области. Разработанные гранулированные азотсодержащие удобрения по эффективности действия в пересчете на внесенный нитратный азот превосходят традиционное удобрение - аммиачную селитру. Их использование позволяет снизить уровень загрязнения почв и грунтовых вод в районах земледелия.

Полученные результаты показывают целесообразность продолжения дальнейших полевых исследований для подтверждения ростостимулирующего эффекта разработанных гранулированных азотсодержащих удобрений на основе сосновых опилок в различных климатических условиях и определения эффекта его пролонгированного действия.

\section{Список литературы / References}

1. Информационно-технический справочник по наилучшим доступным технологиям ИТС 1-2015: Производство иеллюлозы, древесной массы, бумаги, картона. М.: БюроНДТ, 2015. 465 c. [A best available technologies reference document BREF 1-2015: Production of cellulose, wood pulp, paper, cardboard. M.: The NTD Bureau, 2015. 465 p. (in Russ.)]

2. Morozov D., Morozova I., Vasilyev S. The use of soft sawmill waste for the production of fuel briquettes (Review). Resources and Technoloy 2018. Vol. 15, Iss.3, P. 1-28 (in Russ.)

3. Беловежец Л.А., Волчатова И.В., Медведева С.А. Перспективные способы переработки вторичного лигноцеллюлозного сырья. Химия растительного сырья. 2010. № 2, С. 5-16. [Belovezhets L.A., Volchatova I. V., Medvedeva S. A. Promising methods of processing secondary lignocellulose raw materials. Chemistry of plant raw materials. 2010. No. 2, P. 5-16 (in Russ.)]

4. Кудеяров В.Н. Баланс азота, фосфора и калия в земледелии России. Агрохимия 2018. № 10, C. 3-11. [Kudeyarov V.N. Balance of nitrogen, phosphorus and potassium in agriculture in Russia. Agrochemistry. 2018. No. 10, P. 3-11 (in Russ.)]

5. Azeem B., Kushaari K.Z., Man Z. B. et al. Review on materials \& methods to produce controlled release coated urea fertilizer. Journal Control. Release. 2014. Vol. 181, P. 11-21. 
6. Позин М.Е. Технология минеральных солей (удобрений, пестицидов, промышиленных солей, окислов и кислот): часть 2, изд. 4. Л.: Химия, 1974. 768 с. [Pozin M.E. Technology of mineral salts (fertilizers, pesticides, industrial salts, oxides and acids): part 2, ed. 4. L .: Chemistry, 1974. 768 p. (in Russ.)]

7. Stefan Frodeson, Gunnar Henriksson, Jones Berghel. Pelletizing Pure Biomass Substances to Investigate Mechanical Properties and Bonding Mechanisms. Bioresources 2018. Vol. 13, Iss. 1, P. $1202-1222$.

8. Белаш М.Ю., Веприкова Е.В., Иванов И.П., Кузнецов Б.Н., Чесноков Н.В. Получение пористых материалов различного назначения из луба коры березы. Химия в интересах устойчивого развития. 2019. Т. 27. № 5, C. 453-459. [Belash M. Yu., Veprikova E. V., Ivanov I. P., Kuznetsov B.N., Chesnokov N.V. Obtaining porous materials from birch bark bestfor various purposes. Chemistry For Sustainable Development. 2019. Vol. 27. No. 5, P. $453-459$ (in Russ.)]

9. Оболенская А.В., Ельницкая 3.П., Леонович А.А. Лабораторные работь по химии древесины и целлюлозы. М.: Экология, 1991. 320 с. [Obolenskaya A.V., Elnitskaya Z.P., Leonovich A. A. Laboratory work on the chemistry of wood and cellulose. M.: Ecology, 1991. 320 p. (in Russ.)]

10. Рынкевич М. Физические и механические свойства пеллет из сосновых опилок и коры. Вестник ВНИИМЖ 2013. Т. 11, № 3, С. 181-187. [Rynkevich M. Physical and mechanical properties of pellets from pine sawdust and bark. VNIIMZH Bulletin 2013. Vol. 11, No. 3, P. 181-187 (in Russ.)]

11. ISO 9277:2010-09 (E). Determination of the specific surface area of solids by gas adsorptionBET method.

12. Грег С., Синг К. Адсорбция, удельная поверхность, пористость. М.: Мир, 1984. 306 с. [Greg S., Sing K. Adsorption, specific surface area, porosity. Moscow: Mir, 1984. 306 p. (in Russ.)]

13. Доспехов Б.А. Методика полевого опыта. М.: Агропромиздат, 1985. 352 с. [Dospekhov B. A. Field experiment technique. M .: Agropromizdat, 1985. 352 p. (in Russ.)]

14. Методические рекомендаџии по оценке качества зерна. М.: ВАСХНИЛ, 1978. $171 \mathrm{c.}$ [Methodical recommendations for assessing the quality of grain. M.: AUAASNAL, 1978. 171 p. (in Russ.)]

15. Александрова Л.Н., Найденова О. А. Лабораторно-практические занятия по почвоведению. Л.: Колос, 1967. 350 с. [Aleksandrova L.N., Naydenova O. A. Laboratory and practical classes in soil science. L.: Kolos, 1967. 350 p. (in Russ.)]

16. Снедекор Дж.У. Статистические методы в применении и исследованиях в сельском хозяйстве и биологии. М.: Из-во с.-х. литературы, 1961. 503 с. [Snedecor J. W. Statistical methods in application to research in agriculture and biology. M.: Agricultural literature publishing house, 1961. 503 p. (in Russ.)]

17. Фенгел Д., Вегенер Г. Древесина. Химия, ультраструктура, реакции. М.: Лесная промышленность, 1988. 512 с. [Fengel D., Wegener G. Wood. Chemistry, ultrastructure, reactions. M.: Lesnaya promushlrnnost, 1988. 512 p. (in Russ.)]

18. Гаврилов А.Б., Горяинов С.И., Мариничев А.А., Гесслер Н.Н., Кляйн О.И., Исакова Е.П., Дерябина Ю. М. Состав полифенолов в биоматериалах российских хвойных пород. Химия растительног осырья 2019. № 2, С. 51-58. [Gavrilov A. B., Goryainov S. I., Marinichev A. А., 
Gessler N.N., Klein O. I., Isakova E. P., Deryabina Yu. M. Composition of polyphenols in biomaterials of Russian conifers. Chemistry of Plant Raw Materials 2019. No. 2, P. 51-58 (in Russ.)]

19. Прусакова Л.Д., Кефели В.И., Белопухова С. Л., Вакуленко В. В., Кузнецова С.А. Роль фенольных соединений в растениях. Агрохимия 2008. № 7, C. 86-96. [Prusakova L. D., Kefeli V.I., Belopukhova S.L., Vakulenko V.V., Kuznetsova S.A. The role of phenolic compounds in plants. Agrochemistry 2008. No. 7, P. 86-96 (in Russ.)]

20. Sokrates G. Infrared and Raman characteristic group frequencies: Tables and charts. West Sussex: Wiley Sons, 2001. 347 p. 